\title{
ВИЗУАЛЬНЫЙ ПЛАСТ
}

DOI $10.37386 / 2305-4077-2020-2-117-128$

\author{
Л. Д. Апушкина ${ }^{1}$ \\ Санкт-Петербургский государственный институт культуры
}

С. А. Никитченко ${ }^{2}$

Санкт-Петербургский государственный университет

С. Н. Троцюк ${ }^{3}$

Российский государственный гидрометеорологический университет

\section{ИЗОБРАЖЕНИЕ Н.В. ГОГОЛЯ, ЕГО КНИГ И ГЕРОЕВ ЕГО ПРОИЗВЕДЕНИЙ В СОВРЕМЕННОМ ИСКУССТВЕ (НА ПРИМЕРЕ СТРИТ-АРТА)}

В статье приведены примеры изображения Н.В.Гоголя и его героев на стенах городов России, Украины и Казахстана. Эти работы стрит-арта разделяются на: 1) портреты писателя, 2) изображения его персонажей, а также 3) его книг - среди других на книжной полке. Объяснены основные причины, почему художники выбирают Гоголя и его произведения. Раскрывается роль стрит-арта, его ориентация на молодежное восприятие.

Ключевые слова: современное искусство, образ Н.В.Гоголя, герои его произведений, стрит-арт, граффити, мурал.

\section{D. Apushkina \\ St. Petersburg State Institute of Culture \\ S. A. Nikitchenko \\ Saint Petersburg State University \\ S. N. Trotsyuk \\ Russian State Hydrometeorological University \\ The IMAGE OF N. V. GogOL, HIS BOOKS AND CHGARACTERS IN THE CONTEMPORARY ART (A STUDY OF STREET ART)}

The article provides examples of images of Gogol and the characters of his books in the cities of Russia, Ukraine and Kazakhstan. These works of street art are divided into: 1) portraits of the writer, 2) images of his characters, and 3) his books - among others on the bookshelf. The authors attempt to explain the main reasons for street artists' choosing Gogol for their work, the role of street art and its focus on youth perception. The study was facilitated by the StartUp Gogolfest International Festival.

1 Лидия Дмитриевна Апушкина, студентка 4 курса бакалавриата библиотечноинформационного ф-та Санкт-Петербургского государственного института культуры (СПбГИК)

${ }^{2}$ Софья Алексеевна Никитченко, студентка 1 курса магистратуры филологического ф-та Санкт-Петербургского государственного университета (СПбГУ)

${ }^{3}$ Светлана Николаевна Троцюк, кандидат филологических наук, доцент кафедры русского языка Российского государственного гидрометеорологического университета (РГГМУ). 
Keywords: the contemporary art, the image of N. V. Gogol, the characters of Gogol's works, street art, graffiti, a mural.

Одной из важнейших составляющих в эстетике каждого культурного человека является способность воспринимать произведения изобразительного искусства. Оно развивается постоянно и динамично, видоизменяя свои формы, направления и способы выражения. С каждым витком развития это искусство обретает все большую свободу самовыражения, а с ней и эпатажность. То есть художники наделяют свои работы смыслом, зачастую скрытым от массовой аудитории, а это вызывает у обывателей неприятие современного искусства.

Одним из популярных видов современного искусства становится стритарт - уличное искусство, использующее пространство города как холст. Сейчас практически повсеместно во всех странах можно найти работы и начинающих, и давно известных граффитистов. Некоторые из них уже получили признание и одобрение общественности за свой «голос» и свободу самовыражения, неповторимый стиль, особую мотивацию...

В России восприятие стрит-арта неоднозначно. Некоторые граждане активножалуютсянапоявлениехудожественныхработнаулице, причемнезависимо от их местоположения, качества и сложности выполнения. Подобная гражданская активность иногда приводит к закрашиванию уличных образцов художественного творчества. Однако большая часть общественности всячески выражает любовь к искусству такого рода. Примерами могут служить приравнивание стрит-арта к городским достопримечательностям, информирование граждан о появлении новых образцов стрит-арта через официальные СМИ, проведение конкурсов и тендеров для «облагораживания территории», ее украшения стрит-артом, различные выставки, арт-пространства, музеи и т.п.

Произведения стрит-арта, за редким исключением,-это способ выразить свои эмоции, акцентировать внимание общественности на определенной проблеме, поделиться интересами, выразить благодарность и/или уважение к общезначимому событию или известной персоне - например, писателю, поэту... По всему миру можно встретить портреты классиков или отсылки к их произведениям, выполненные на стенах города уличными художниками. В России чаще всего такие работы посвящены Пушкину как самому известному российскому классику. Но есть немало работ, связанных с Николаем Васильевичем Гоголем.

Прежде чем приступить к непосредственному анализу такого стритарта, стоит отметить мероприятие международного масштаба, посвященное Гоголю, которое проходит ежегодно с 2007 г. и вошло в ТОП-5 мероприятий Европы за 2019 г. Это Международный фестиваль «StartUp Гогольfest». Его программа в 2019 г. растянулась на 6 дней и насчитывала 13 площадок и около 150 проектов: образовательных, детских, перформативных программ, театральных и музыкальных концертов, мастер-классов, квестов и проч. Особенностью фестиваля стала презентация Международного фестиваля «StartUp Гогольfest» и совместного проекта Гогольfest и ГогольTrain, проходившая на железнодорожном вокзале в Киеве. 
ГогольTrain - первый в Европе арт-поезд, который объединяет искусство, города и людей на платформе культурной мобильности.

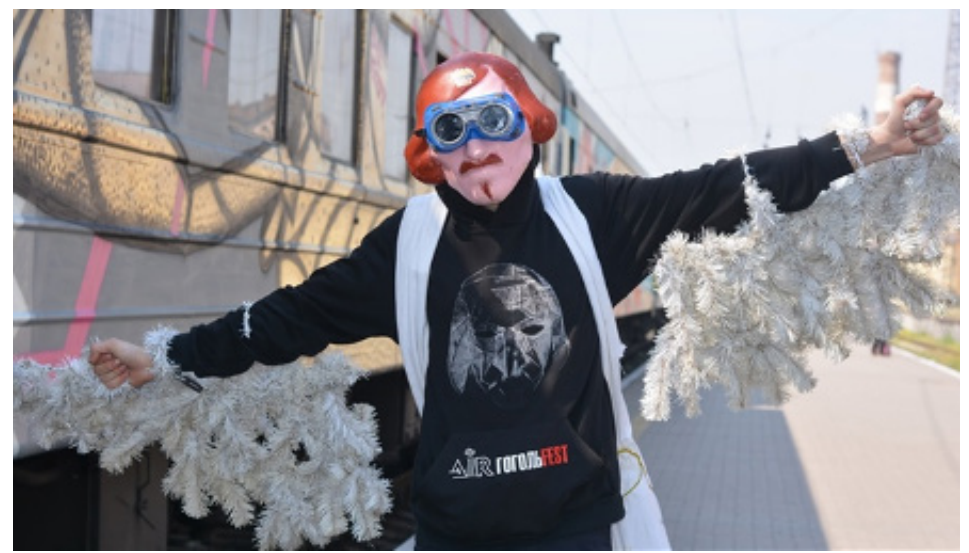

(рис. 1)

В фестивале приняли участие многие медийные личности и представители культуры (среди них министр инфраструктуры Украины Владимир Емельян, директор фестиваля современного искусства «Гогольfest» Максим Демский, программный директор «Гогольfest» Анна Басова, креативный директор ГогольТrain Денис Угорчук, куратор театральной программы Андрей Палатный, советник посольства Дании в Украине по вопросам общественной дипломатии Сергей Матюшенко и др.). А театральная программа фестиваля подтвердила известность и актуальность гоголевского творчества в Европе - в нее вошли спектакли из Германии, Италии, Швейцарии, Австрии, Литвы и Польши ${ }^{4}$.

Показав огромное влияние произведений Н.В.Гоголя на современное искусство, можно перейти к его изобразительным, более локальным формам: граффити и муралам. Граффити - это изображения или надписи, которые выцарапаны, написаны или нарисованы на стенах и прочих поверхностях; к ним относятся все виды уличного раскрашивания: от просто написанных слов до изысканных рисунков (чаще всего - аэрозольных). Мурал - очень большое уличное искусство, как правило, это картина на стене здания, придающая ему красоту. В крупных городах муралы размещаются на глухих стенах домов, на больших заграждениях или в подземных переходах. Это действительно произведения искусства: они передают какую-то глубокую идею или смысл и тем самым ближе к классическим фрескам, изображавшим сцены из жизни или мифологии. Кроме того, муралы обычно создаются по согласованию с городской властью и в большинстве случаев выглядят вполне реалистично: практически как фотографии на стенах.

4 В Киеве презентовали арт-поезд «Гогольtrain», который отправится в Мариуполь.[Электрон. pecypc] https://www.0629.com.ua/news/2371142/v-kieve-prezentovali-art-poezdgogoltrain-kotoryj-otpravitsa-v-mariupol-foto (здесь и далее дата обращения: 09.12.2019). 
Подобные работы стрит-арта, связанные с Гоголем и его творчеством, можно разделить на:

- портреты самого писателя;

- визуализацию персонажей его произведений;

- изображение его книг на книжной полке, в том числе среди работ других авторов.

Существует много современных портретов Н.В.Гоголя, выполненных уличными художниками различной техникой в городах России, Украины и Казахстана. Вот, например, портрет Н.В. Гоголя в г. Томске на пересечении ул. Гоголя с пер. Плеханова (рис. 2 и 3). Этот стрит-арт - работа участников молодежного движения «Кислород», которые по проекту public space «Аллея Гоголя» (2012) «окультурили» заброшенное место недалеко от центра города.

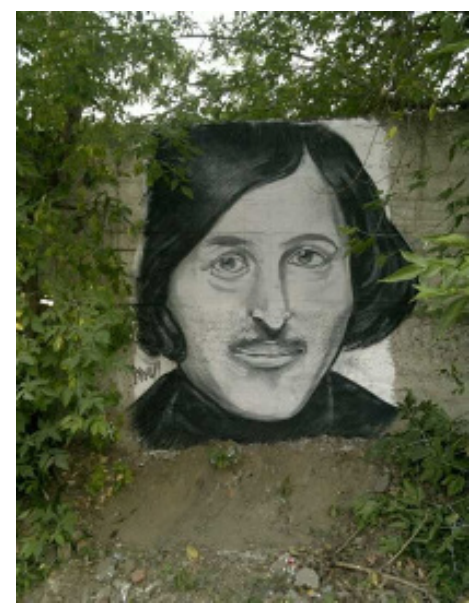

(рис. 2)

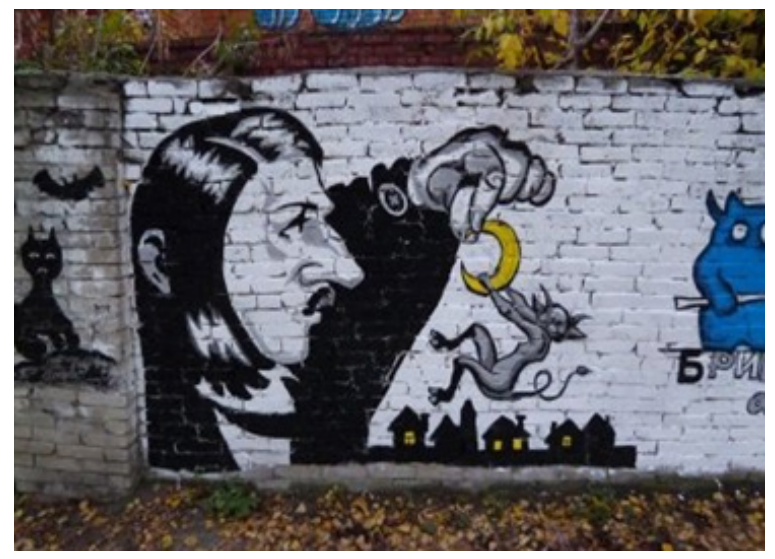

(рис. 3) 
Проект получил имя «Аллея Гоголя» (по названию близлежащей улицы и трамвайной остановки). Кроме основного портрета писателя, существуют еще изображения, где он взаимодействует с героями своих произведений 5 .

Другой арт-объект расположен также на ул. Гоголя в г. Харькове. Сама улица выглядит довольно живописно из-за архитектуры некоторых зданий и, наверное, истории. Особый колорит ей добавляют оригинальные граффити (не только на этой улице, но и во всем городском пространстве). Эти работы Гамлета Зиньковского и Романа Минина за те годы, что граффити украшают стену, стали узнаваемыми и популярными (рис. 4 и 5).

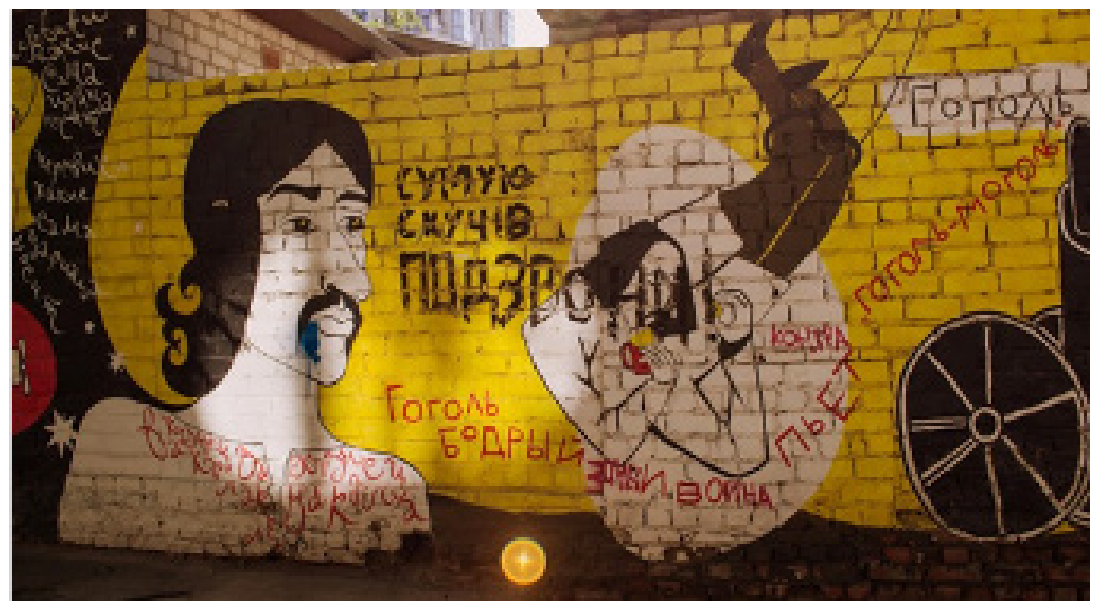

(рис. 4)

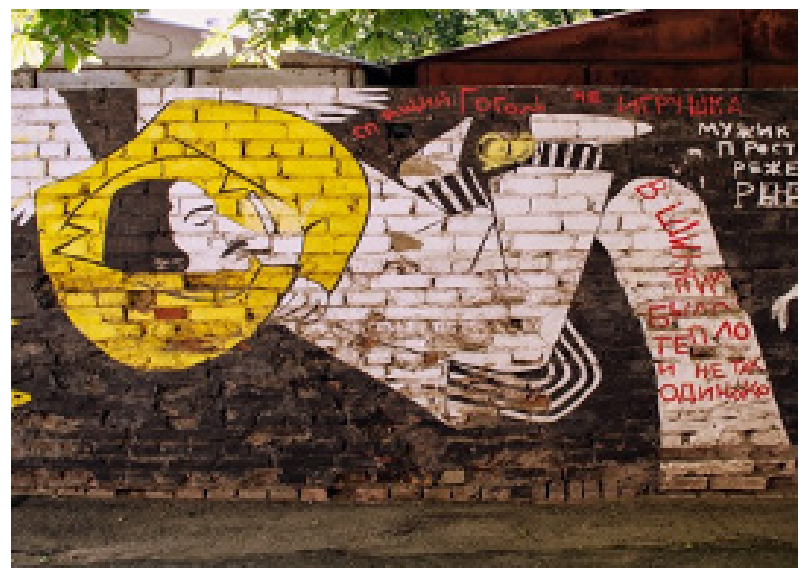

(рис. 5)

${ }^{5}$ «Strannye ljudi» sozdadut v Tomske Alleju Gogolja dlja progulok i otdyha.-[Jelektron. resurs]: https://ria.ru/20120720/497552387.html 
На желтом фоне изображены фигуры (в основном, Гоголя) и помещены надписи к ним. Стрит-арт создавался в рамках проекта муниципальной галереи «Пушкин на Пушкинской и Гоголь на Гоголя» ${ }^{6}$ и находится на ул. Гоголя, 4. Достопримечательностью улицы также является табличка с двумя Гоголями.

Еще одним примером актуального изображения Н.В.Гоголя (рис. 6) выступает работа размером более $50 \mathrm{~m}^{2}$ в г. Алматы (Казахстан), расположенная на восточной стене центрального магазина «Меломан» на ул. Гоголя, 58. Художник Andrew Repas изобразил писателя в стиле ретровейва - это стиль электронной музыки, появившийся в середине 2000-х годов. Цитата «Rise my eyelids!» («Поднимите мне веки!») взята из повести «Вий» 7 .

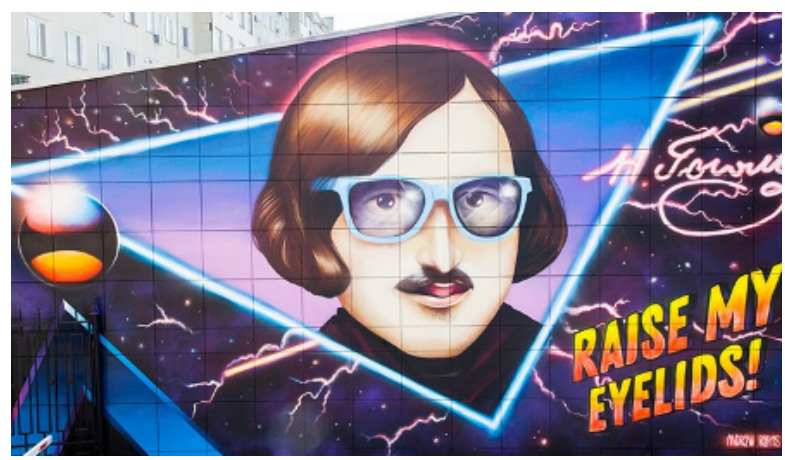

(рис. 6)

Уличное искусство становится все более популярным в г. Екатеринбурге. Жители уже не воспринимают это как проявление вандализма, а стремятся понять суть высказываний художника, проникнуться ими. В результате улица выступает средством коммуникации между обществом, художником и зрителем.

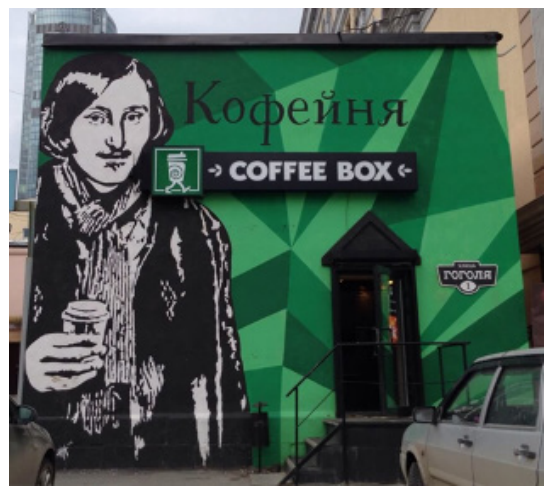

(рис. 7)

${ }^{6}$ Стрит-арт на улице Гоголя, Харьков. [Электрон. ресурс]

${ }^{7}$ Граффити и муралы Алматы.- [Электрон. ресурс]. URL: https://www.the-village.kz/village/ city/city-guide/2507-its-not-a-city-its-a-museum . 
Таков, например, коммерческий проект: портрет писателя в модно повязанном шарфе и со стаканчиком кофе (рис. 7) - как реклама «для своих» ${ }^{8}$.

На этом список арт-объектов, посвященных Н.В.Гоголю, отнюдь не исчерпывается. Из вышесказанного можно сделать вывод, что подобные муралы выполняют различные функции: облагораживание пространства, привлечение внимания, брендирование.

Кроме того, они являются результатом или коммерческого заказа, или инициативы местных властей. Такие объекты современного арт-искусства объединяются, как правило, их местоположением на улице Гоголя в различных городах бывшего СССР.

Следующую категорию: «Изображение героев произведений Н. В. Гоголя» - начнем с показательно необычного стрит-арта на стене воинской части в с. Клугино-Башкировка (Украина). Это мурал художника Андрея Янкова, изображающий героев гоголевской повести «Тарас Бульба» (рис. 8). Благодаря такому местоположению картина получает дополнительную функцию патриотического воспитания, кроме культурного и духовного развития граждан.

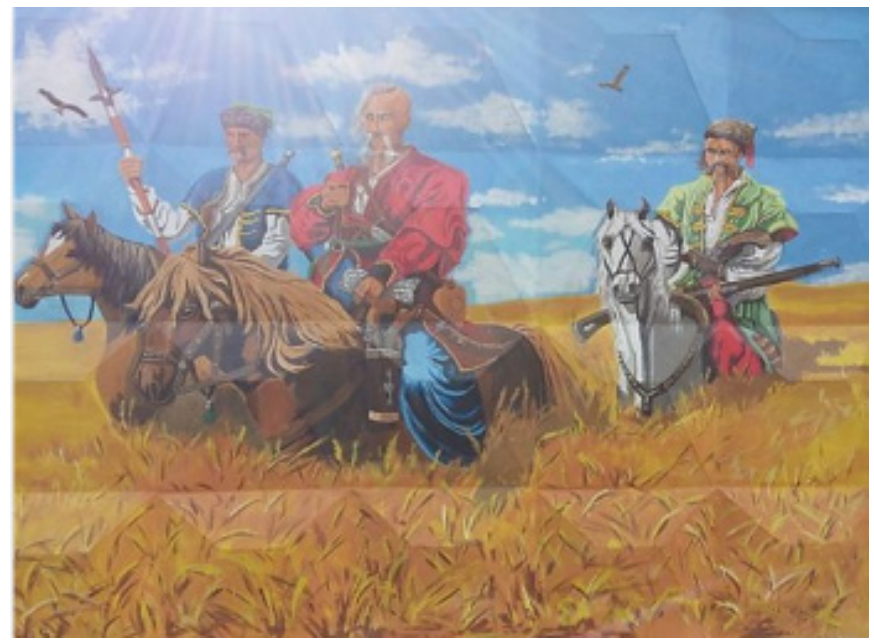

(рис. 8)

Мы уже упоминали о public space «Аллея Гоголя» в г. Томске. Кроме портретов писателя, в том же пространстве находятся изображения: Пацюка из повести «Ночь перед Рождеством» (рис. 9), которого многие принимают за Тараса Бульбуํㅜㄹ а также панночки, держащей записку, из повести «Майская ночь, или Утопленница»

\footnotetext{
8 Экскурсия по стрит-арт объектам Екатеринбурга.- [Электрон. ресурс].

${ }^{9}$ На примере томской аллеи Гоголя сибирякам покажут, как из трущоб сделать публичное место.- [Электрон. ресурс]. URL: http://tomsk-novosti.ru/na-primere-tomskoj-allei-gogolyasibiryakam-pokazhut-kak-iz-trushhob-sdelat-publichnoe-mesto/
} 


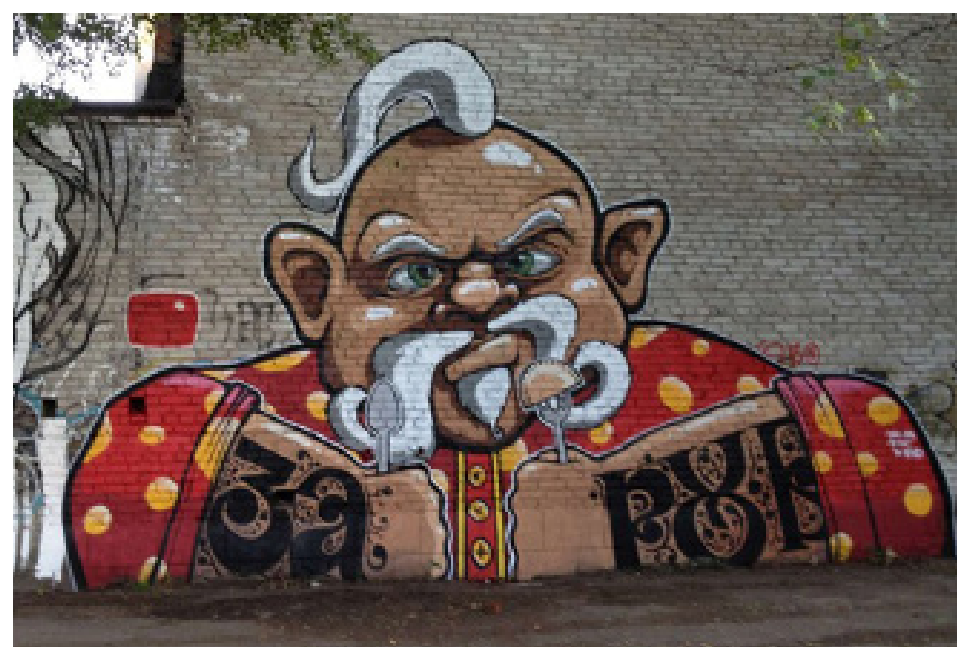

(рис. 9)

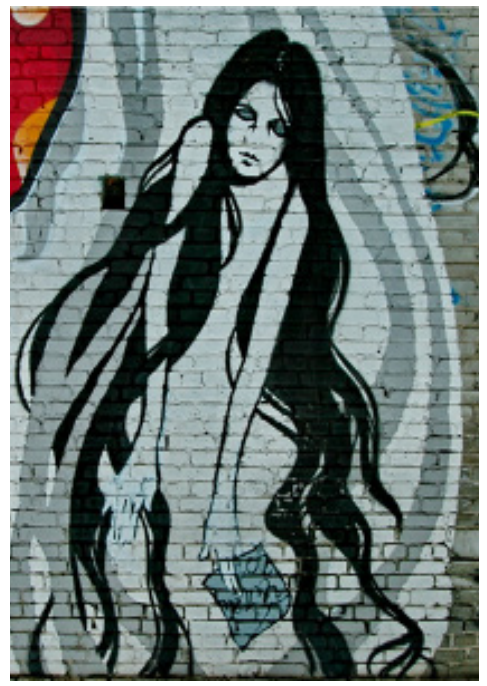

(рис. 10).

Еще один пример обдуманного стрит-арта - иллюстрация к повести Гоголя «Ночь перед Рождеством» из сборника «Вечера на хуторе близ Диканьки» (рис. 11), а также изображение героев повести «Тарас Бульба» (рис. 12). Примечательно, что в г. Краснодаре данный стрит-арт изображен на стене, возле которой нет достопримечательностей культурного характера, однако именно по этой улице проложены трамвайные пути, соединяющие между собой две библиотеки: Краевую юношескую библиотеку им. И. Ф. Вараввы и Детскую библиотеку им. В. Б. Бакалдина. Стрит-арт расположен на середине пути. 


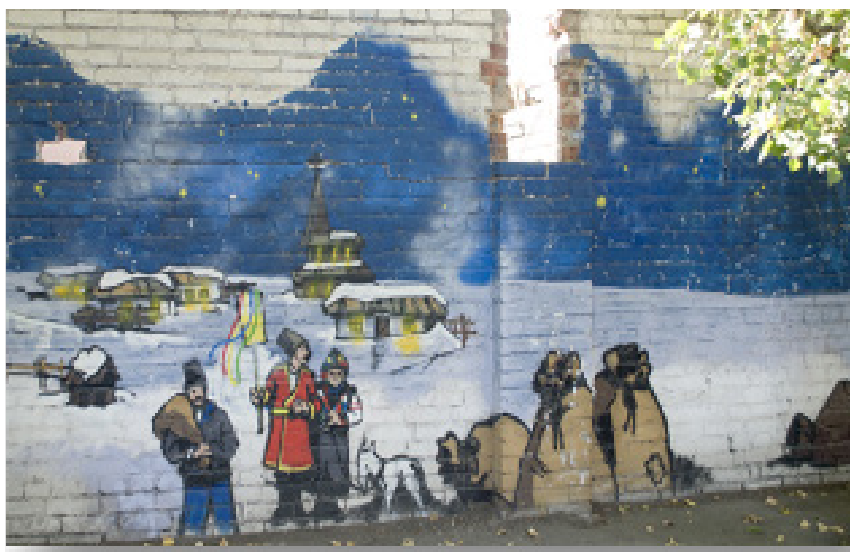

(рис. 11)

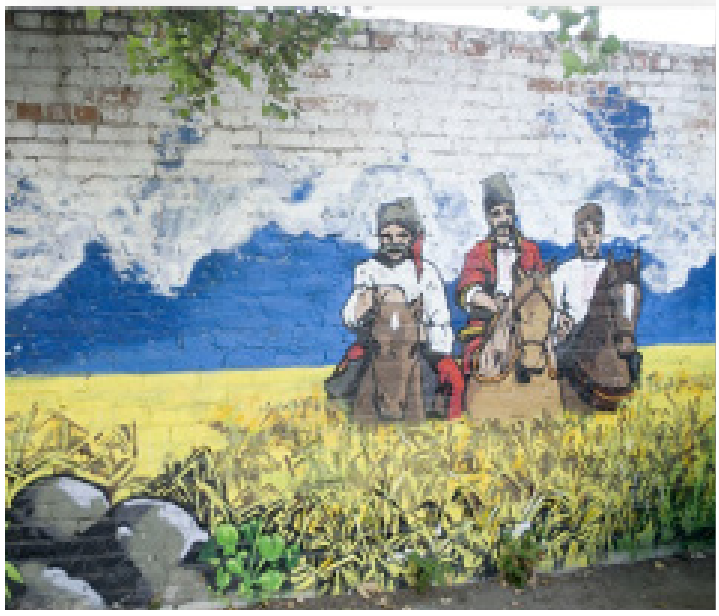

(рис. 12)

Всё это отнюдь не исчерпывает список подобных изображений. Среди них чаще всего встречаются фрагменты из повести «Тарас Бульба». Следующая категория примечательна тем, что все упомянутые арт-объекты - вполне легальные и/или коммерческие. Так, в 2014 г. граффити-художник Алексей Есин (АлексТрикс) одну из стен начальной школы № 43 в г. Череповце превратил в полку с книгами (рис. 13). Таким образом, данный стрит-арт был санкционирован для восприятия учащимися. Его целью было приобщить младших школьников к чтению и популяризировать классическую литературу ${ }^{10}$

10 Граффити (так же, как и стрит-арт) должны украшать стены, а не уродовать их.[Электрон. peсурс] https://pikabu.ru/story/graffiti_tak_zhe_kak_i_stritart_dolzhnyi_ukrashat_ stenyi_a_ne_urodovat_ikh_96_6701932 


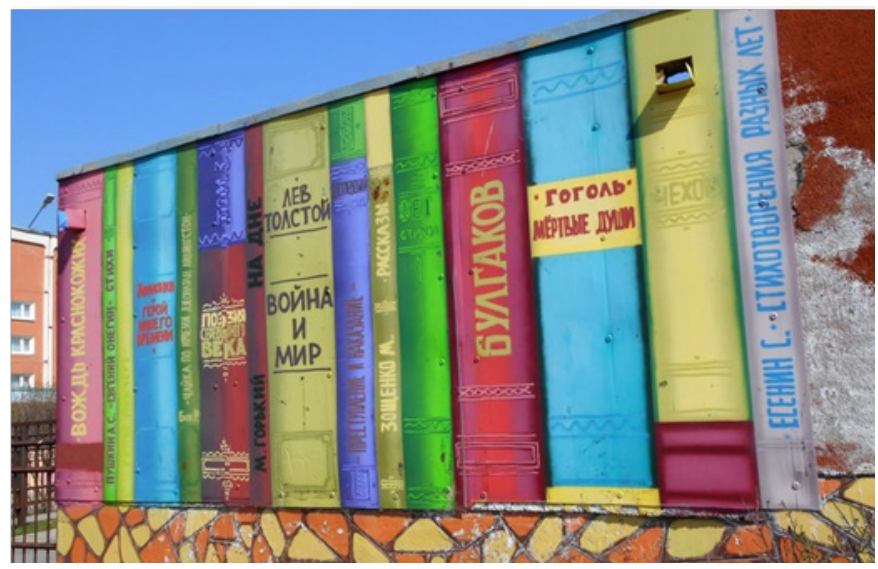

(рис. 13)

Книжная полка также украсила фасад другого образовательного учреждения - гимназии № 5 в г. Тюмени. Этот объект (рис. 14) вошел в список лучших стрит-артов всего мира по версии ресурса Adme.ru в 2012 г. Но стоит отметить, что во многих школах Тюмени стены расписаны портретами писателей и/или цитатами из их произведений. Всем этим занимается объединение «Молодёжная атмосфера».

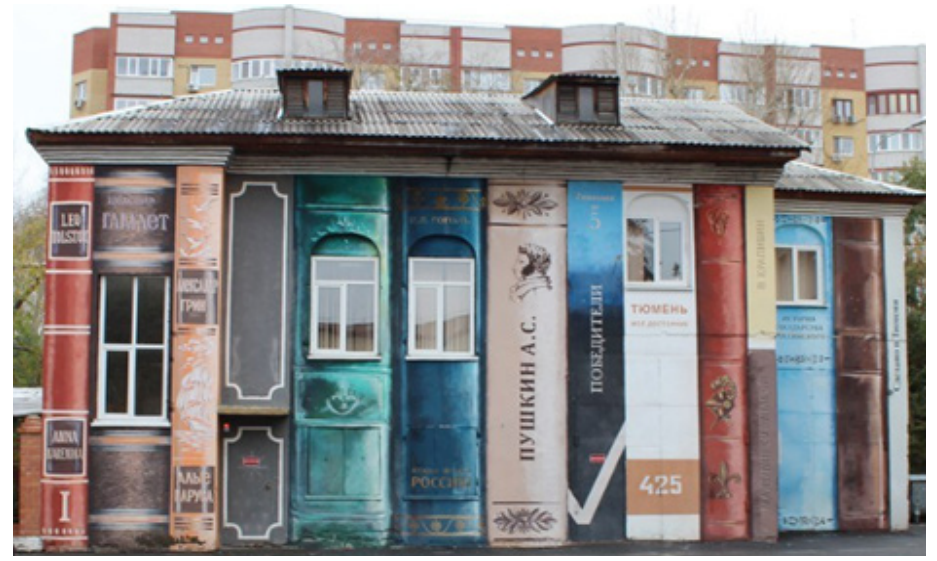

(рис. 14)

И последний стрит-арт в этой категории - книжная полка в СанктПетербурге (рис. 15). Компания «ТЭК СПб» в 2011 г. запустила проект образования детей и привлечения их внимания к вопросам безопасности. На кирпичном фасаде трансформаторной подстанции появилось изображение нескольких произведений классической русской литературы, а среди них - «Ночь перед Рождеством» Н. В. Гоголя. 


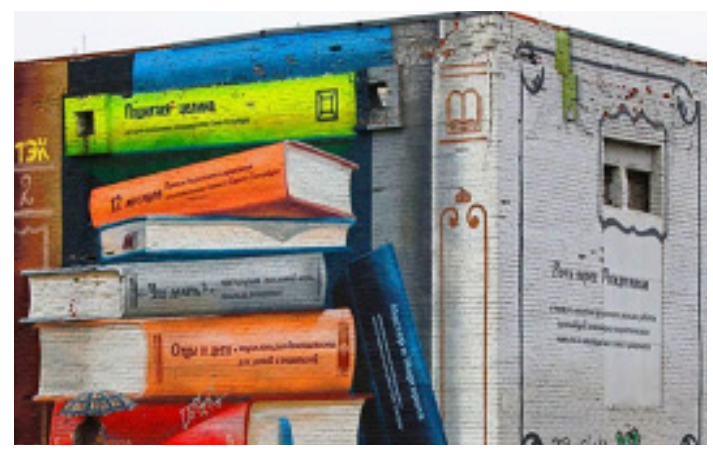

(рис. 15)

Как мы видели, великому писателю и персонажам его произведений посвящено немало произведений стрит-арта, и теми, что были упомянуты в нашей статье, этот ряд отнюдь не исчерпывается: достойны внимания еще многие работы.

1. Разделение их на категории обусловлено различными функциями:

2. Некоторые портреты Н.В. Гоголя прямо связаны с названием улицы, где они изображены, и являются своеобразным брендом этой улицы.

3. Изображения персонажей из гоголевских произведений, что находятся в культурно значимых местах (арт-пространство, между библиотеками и т. п.), имеют явно просветительский и/или воспитательно-патриотический характер.

4. Изображения книжных полок изначально задумывались для популяризации чтения классики и потому непосредственно приближены к своему адресату - школьникам.

Таким образом, и легальный (в качестве коммерческих проектов), и нелегальный стрит-арт (как инициатива социально активных граждан) направлен на поддержку классической литературы. Всё это должно привлечь молодых читателей к ее новому прочтению. Подобная тенденция и передается изображениями писателей, их книг, персонажей их произведений на стенах городов.

\section{СПИСОК ЛИТЕРАТУРЫ}

Авангард в культуре ХХ века. 1900-1930 гг. Теория. История. Поэтика : в 2 кн. / под ред. Ю. Н. Гирина. - Москва : ИМЛИ РАН, 2010. Кн. 1. - 704 с.

Голдберг, Р.Искусство перформанса. От футуризма до наших дней / Р. Голдберг. - Москва : Ад Маргинем Пресс, 2014. -318 с.

Дадаизм в Цюрихе, Берлине, Ганновере и Кельне : тексты, иллюстрации, документы / отв. ред. К. Шуман. - Москва : Республика, 2001. -512 с. $191 \mathrm{c}$.

Дебор, Г. Общество спектакля / Г. Дебор. - Москва : Опустошитель, 2014. -

Дебор, Г.Психогеография / Г.Дебор. - Москва : Ад Маргинем Пресс, 2017. -217 c. 
Рихтер, Г. ДАДА : искусство и антиискусство / Г. Дада. -Санкт-Петербург : Гилея, 2014. -320 с.

Тарасов, А. Ситуационисты и город / А. Тарасов // Художественный журнал. - 1999. - № 24. - С. 29-33.

Фещенко, В. В. Сотворение знака : очерки о лингвоэстетике и семиотике искусства / В. В. Фещенко, О.В.Коваль. - Москва : Языки славянской культуры, 2014. $-640 \mathrm{c}$.

Юренева, Т. Ю. Музееведение / Т. Ю. Юренева. - Москва : Академический проект, 2004. - 544 c.

Bacharach, C. Street Art and Consent / C. Bacharach // The British Journal of Aesthetics. - 2015. Vol. 55. Iss. 4. - P. 481-495.

Lewisohn, C. Street Art : The Graffiti Revolution / C. Lewisohn. C.. L. : Tate Publishing, 2009. - $144 \mathrm{p}$.

Riggle, N. Street Art : The Transfiguration of the Commonplace / N. Riggle // Journal of Aesthetics and Art Criticism. - 2010. Vol. 68. - № 3. P. 243-257.

Waclawek, A. Graffiti and Street Art. - N. Y. : Thames \& Hudson, 2011. - 320 p. REFERENCES:

Avangard v kul'ture XX veka. 1900-1930 gg. Teoriya. Istoriya. Poetika : v 2 kn. / pod red. YU.N. Girina. - Moskva : IMLI RAN, 2010. Kn. 1. -704 s.

Goldberg, R. Iskusstvo performansa. Ot futurizma do nashih dnej / R. Goldberg. Moskva : Ad Marginem Press, 2014. -318 s.

Dadaizm v Cyurihe, Berline, Gannovere i Kel'ne : teksty, illyustracii, dokumenty / otv. red. K. SHuman. - Moskva : Respublika, 2001. -512 s.

Debor, G. Obshchestvo spektaklya / G. Debor. - Moskva : Opustoshitel', 2014. $-191 \mathrm{~s}$. $217 \mathrm{~s}$.

Debor, G. Psihogeografiya / G. Debor. - Moskva : Ad Marginem Press, 2017. -

Rihter, G. DADA : iskusstvo i antiiskusstvo / G. Dada. - Sankt-Peterburg : Gileya, 2014. $-320 \mathrm{~s}$.

Tarasov, A. Situacionisty i gorod / A. Tarasov // Hudozhestvennyj zhurnal. 1999. - № 24. - S. 29-33.

Feshchenko, V.V.Sotvorenie znaka : ocherki o lingvoestetike i semiotike iskusstva / V. V. Feshchenko, O. V. Koval'. - Moskva : YAzyki slavyanskoj kul'tury, 2014. $-640 \mathrm{~s}$.

YUreneva, T. YU. Muzeevedenie / T.YU. YUreneva. - Moskva :Akademicheskij proekt, 2004. $-544 \mathrm{~s}$.

Bacharach, C. Street Art and Consent / C. Bacharach // The British Journal of Aesthetics. - 2015. Vol. 55. Iss. 4. - P. 481-495.

Lewisohn, C. Street Art : The Graffiti Revolution / C. Lewisohn. C.. L. : Tate Publishing, 2009. - $144 \mathrm{p}$.

Riggle, N. Street Art : The Transfiguration of the Commonplace / N. Riggle // Journal of Aesthetics and Art Criticism. - 2010. Vol. 68. - № 3. P. 243-257.

Waclawek, A. Graffiti and Street Art. - N. Y. : Thames \& Hudson, 2011. -320 p. 